\title{
PEMBUATAN SET EKSPERIMEN UNTUK MENENTUKAN KOEFISIEN KINETIK DAN KOEFISIEN RESTITUSI
}

\author{
Venny Haris, Novia Lizelwati \\ Jurusan Tadris Fisika IAIN Batusangkar \\ Jl. Sudirman No. 137 Kubu Rajo Lima Kaum Batusangkar 27213 \\ Email:venny_haris@yahoo.com
}

\begin{abstract}
This study aims to determine the design specifications set tool-making experiments to determine the kinetic coefficients and a coefficient of restitution of the collision of two objects using laser diode and sensor based LDR arduino uno. Results of the study is the design tool set of experiments could measure the kinetic coefficient between the glass material with glass with a relative error of $2.5 \%$, wood with wood with a relative error of $1 \%$, and steel materials with wood with a relative error of $0.5 \%$. The coefficient of restitution is obtained for glass with glass material is 0.062 , wood with wood is $0: 49$, and steel materials with wood is $0: 22$.
\end{abstract}

Key words: kinestetic cooficient, restitution, sensor, laser dioda, LDR, arduino uno

\section{PENDAHULUAN}

Fisika merupakan ilmu yang tidak hanya berkutat dengan teori belaka, tapi harus diiringi dengan kegiatan eksperimen. Kegiatan eksperimen dilakukan untuk melengkapi pengalaman belajar bagi siswa. Melalui kegiatan eksperimen diharapkan siswa semakin mengingat sebuah konsep fisika karena mereka menemukan konsep fisika tersebut melalui pengalaman langsung pada kegiatan eksperimen.

Kegiatan eksperimen bisa dilakukan di laboratorium sekolah menggunakan alat yang tersedia. Akan tetapi, tidak semua konsep fisika tersedia alat eksperimennya. Oleh karena itu dibutuhkan kreatifitas pendidik dalam mengembangkan alat eksperimen yang sesuai dengan konsep fisika yang akan diajarkan. Novia Lizelwati (2010) telah melakukan penelitian untuk mendesain alat ekperimen yang dapat menentukan koefisien gesekan dan koefisien restitusi tumbukan dua benda. Pada penelitian ini ada masalah yang timbul yaitu pengukuran waktu pada gerak balok mulai ditumbuk bola hingga berhenti masih menggunakan stopwatch. Sehingga dibutuhkan penelitian lanjutan menggunakan sistem kontrol. Maisa Fitri tahun 2014 juga sudah mulai menggunakan sistem kontrol dalam pembuatan alat eksperimen yang berjudul Pembuatan Sistem Penentuan Koefisisen Gesek Statis Benda Pada Bidang Miring Secara Digital Berbasis Mikrokontroler menggunakan LED inframerah dan photransistor berbasis mikrotroler (Yohandri, 2014).

Untuk mengatasi kelemahan dari alat eksperimen yang sudah dikembangkan oleh Novia Lizelwati (2010) dan agar data yang didapatkan lebih akurat maka diperlukan alat pendeteksi dengan menggunakan sensor Laser Dioda dan LDR untuk mengukur waktu berbasis mikrokontroler arduino Uno sebagai pengendali. Dimana sistem pengontrolnya bekerja secara otomatis. Penelitian menggunakan mikrokontroler arduino uno sudah ada dilakukan peneliti sebelumnya dalam mengembangkan set alat eksperimen peswat atwood, yang mana ketepatan dari hasil pengukurannya cukup tinggi (Putri,dkk.,2015). 
Laser Dioda adalah sejenis dioda dimana media aktifnya menggunakan sebuah semikonduktor persimpangan $\mathrm{p}$-n yang mirip dengan yang terdapat pada dioda pemancar cahaya. Laser dioda kadang juga disingkat LD atau ILD. Light Dependent Resistor (selanjutnya disebut LDR), terdiri dari sebuah cakram semikonduktor yang mempunyai dua buah elektroda pada permukaannya. Pada saat gelap atau cahaya redup, bahan dari cakram tersebut menghasilkan elektron bebas dengan jumlah yang relatif kecil. Sehingga hanya ada sedikit elektron untuk mengangkut muatan elektrik. Artinya pada saat cahaya redup LDR menjadi konduktor yang buruk, atau bisa disebut juga LDR memiliki resistansi yang besar pada saat gelap atau cahaya redup (Fraden, 2004).

Arduino Uno adalah kit elektronik atau papan rangkaian elektronik open source yang di dalamnya terdapat komponen utama yaitu sebuah chip mikrokontroler dengan jenis AVR dari perusahaan Atmel. Arduino adalah sebuah board mikrokontroller yang berbasis ATmega328. Arduino memiliki 14 pin input/output yang mana 6 pin dapat digunakan sebagai output PWM, 6 analog 13 input, crystal osilator $16 \mathrm{MHz}$, koneksi USB, jack power, kepala ICSP, dan tombol reset. Arduino mampu men-support mikrokontroler dan dapat dikoneksikan dengan komputer menggunakan kabel USB (Kadir, 2013). Bentuk fisik dari papan arduino seperti pada Gambar 1.

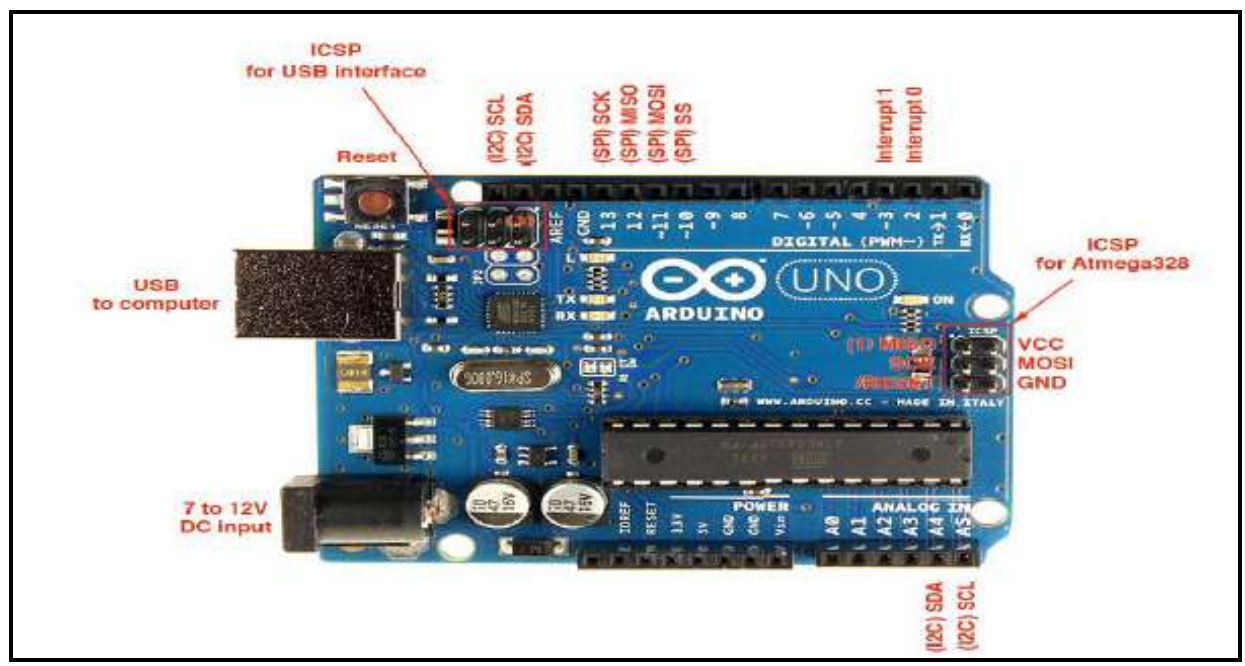

Gambar 1. Bentuk fisik papan arduino (Kadir, 2003)

Berdasarkan latar belakang di atas, maka peneliti tertarik untuk melakukan penelitian dengan judul "Pembuatan Set Eksperimen Untuk Menentukan Koefisien Kinetik dan Koefisien Restitusi Tumbukan Dua Benda Menggunakan Sensor Laser Dioda dan LDR Berbasis Arduino Uno.

\section{METODE PENELITIAN}

\section{Jenis, Waktu dan Tempat Penelitian}

Jenis penelitian ini merupakan eksperimen laboratorium (laboratory eksperimentation). Penelitian dilakukan di Laboratorium Elektronika dan Instrumentasi IAIN Batusangkar. Kegiatan ini dilaksanakan 
selama 6 bulan dimulai bulan Mei 2015 sampai dengan Oktober 2015.

\section{Peralatan dan Bahan}

Dalam melaksanakan penelitian ini peralatan yang digunakan terdiri dari multimeter digital dan solder. Multimeter digital digunakan untuk menentukan nilai komponen yang digunakan seperti resistor dan untuk mengukur nilai tegangan keluaran dari sensor.
Dalam pembuatan alat ukur untuk menentukan koefisien gesekan kinetik dan koefisien restitusi tumbukan dua benda menggunakan batang statif, balok kayu, jalur bidang gesekan, bola logam, busur derajat, sensor Laser Dioda dan LDR, dan mikrokontroler arduino Uno.

\section{Tata Laksana Penelitian}

Secara umum blok diagram sistem secara keseluruhan dapat diperhatikan pada Gambar 2.

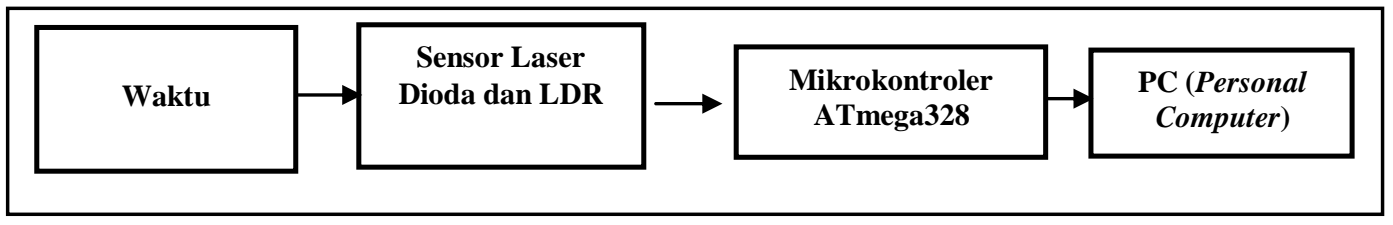

Gambar 2. Blok diagram sistem sensor Laser Dioda dan LDR untuk Koefisien kinetik dan koefisien restitusi tumbukan benda

Gambar 2 menggambarkan blok diagram dari keseluruhan sistem sensor untuk Koefisien kinetik dan koefisien restitusi tumbukan dua benda. Sensor Laser Dioda dan LDR bekerja berdasarkan pada perubahan waktu. Dengan mengatur posisi sensor Laser Dioda dan LDR akan menghasilkan output berupa perubahan tegangan. Sumber tegangan yang digunakan pada sinyal processing adalah $5 \mathrm{~V}$. Besaran tegangan yang dihasilkan oleh sinyal processing diubah menjadi nilai digital melalui mikrokontroler arduino dan mengkonversinya sekon serta menampilkannya pada PC (Personal Computer).

Tahapan kerja yang dilakukan dalam penelitian ini adalah sebagai berikut:

Perancangan Perangkat Sistem Pengukuran

Set alat eksperimen untuk menentukan koefisien gesekan kinetik dan koefisien restitusi tumbukan dua benda menggunakan sistem sensor Laser Dioda dan LDR berbasis arduino uno. Secara umum desain sistem pengukuran pada set eksperimenadalah seperti pada Gambar 3.

Gambar 3 memperlihatkan desain set eksperimen untuk menentukan koefisien kinetik dan koefisien restitusi tumbukan dua benda secara keseluruhan. Desain secara umum terdiri dari atas empat bagian, yaitu bagian tempat menjepit bola logam, bagian kedua sensor Laser Dioda dan LDR, dan bagian ketiga tempat rangkaian mikrokontroler arduino uno dan penampil $(P C)$. Bagian sensor Laser Dioda dan LDR berfungsi untuk mengubah besaran waktu menjadi besaran listrik dalam bentuk tegangan. Tempat rangkaian bagian luarnya terdapat rangkaian mikrokontroler digunakan untuk mengubah nilai tegangan analog yang dihasilkan oleh sensor dan untuk mengubah sinyal sensor menjadi bentuk yang dapat dikonversikan ke nilai digital dalam satuan meter dan sekon. Keluaran pada mikrokontroler akan ditampilkan melalui PC (personal computer) tempat rangkaian mikrokontroler dan penampil $(P C)$. 


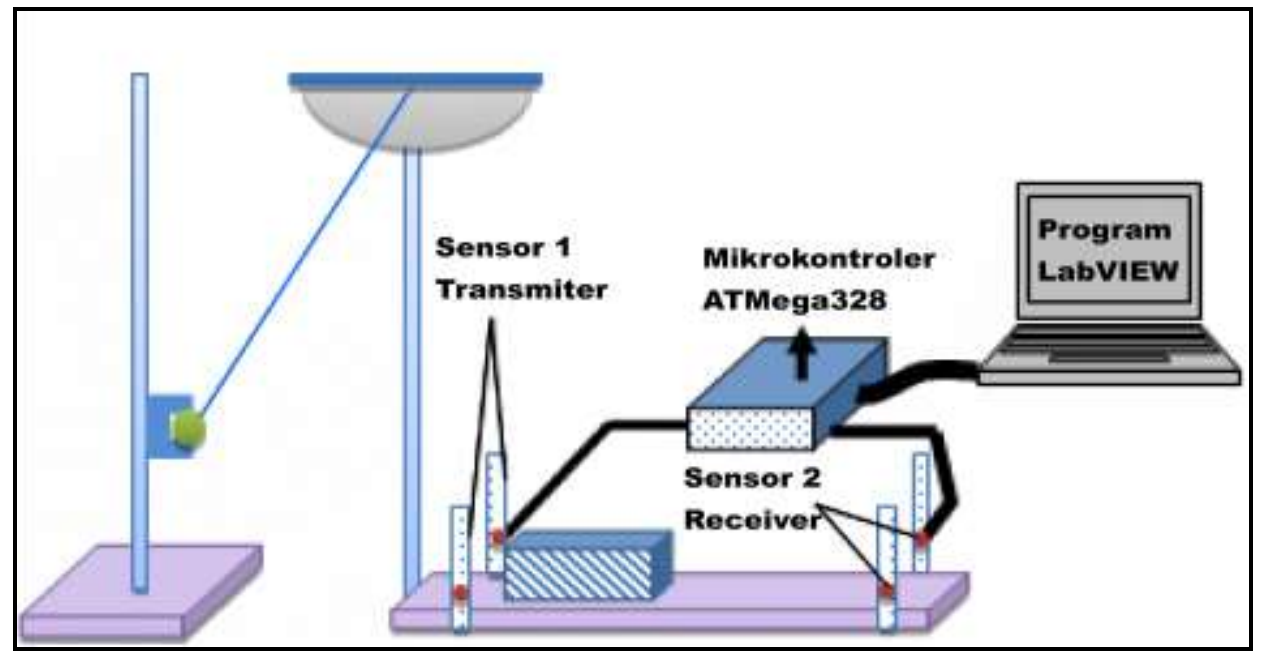

Gambar 3. Desain set eksperimen

\section{Desain perangkat lunak}

Untuk menjalankan suatu sistem instrumentasi diperlukan urutan instruksi yang disebut program. Program sistem alat ukur koefisien gesekan kinetik dan koefisien restitusi tumbukan dua benda yang merubah nilai tegangan menjadi nilai digital pada mikrokontroler ditulis dalam bahasa pemrograman bahasa $\mathrm{C}$ sementara perangkat lunak untuk menampilkan data digital dari mikrokontroler dengan menggunakan LabVIEW Diagram alir perangkat lunak pada mikrokontroler ATmega328 untuk menampilkan perpindahan dan waktu seperti yang ditunjukkan pada Gambar 4.

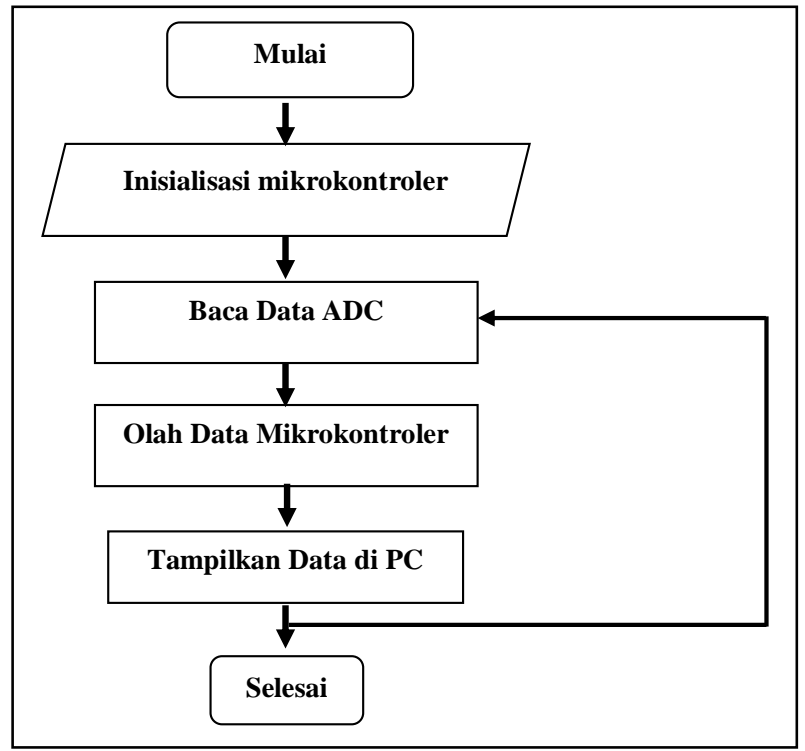

Gambar 4. Diagram alir program sistem pengukuran 
Gambar 4 memperlihatkan diagram alir program, dimana apabila sistem dihidupkan maka akan melakukan inisialisasi terhadap mikrokontroler. Mikrokontroler akan melakukan pengenalan terhadap ADC yang akan mendatangkan data yang akan diproses.
Data diproses berdasarkan perhitungan error dan perubahannya pada sistem. Data yang dihasilkan dari keluaran mikrokontroler akan ditampilkan oleh labview. Program yang dibuat menggunakan perangkat lunak LabView ditampilkan seperti pada Gambar 5.

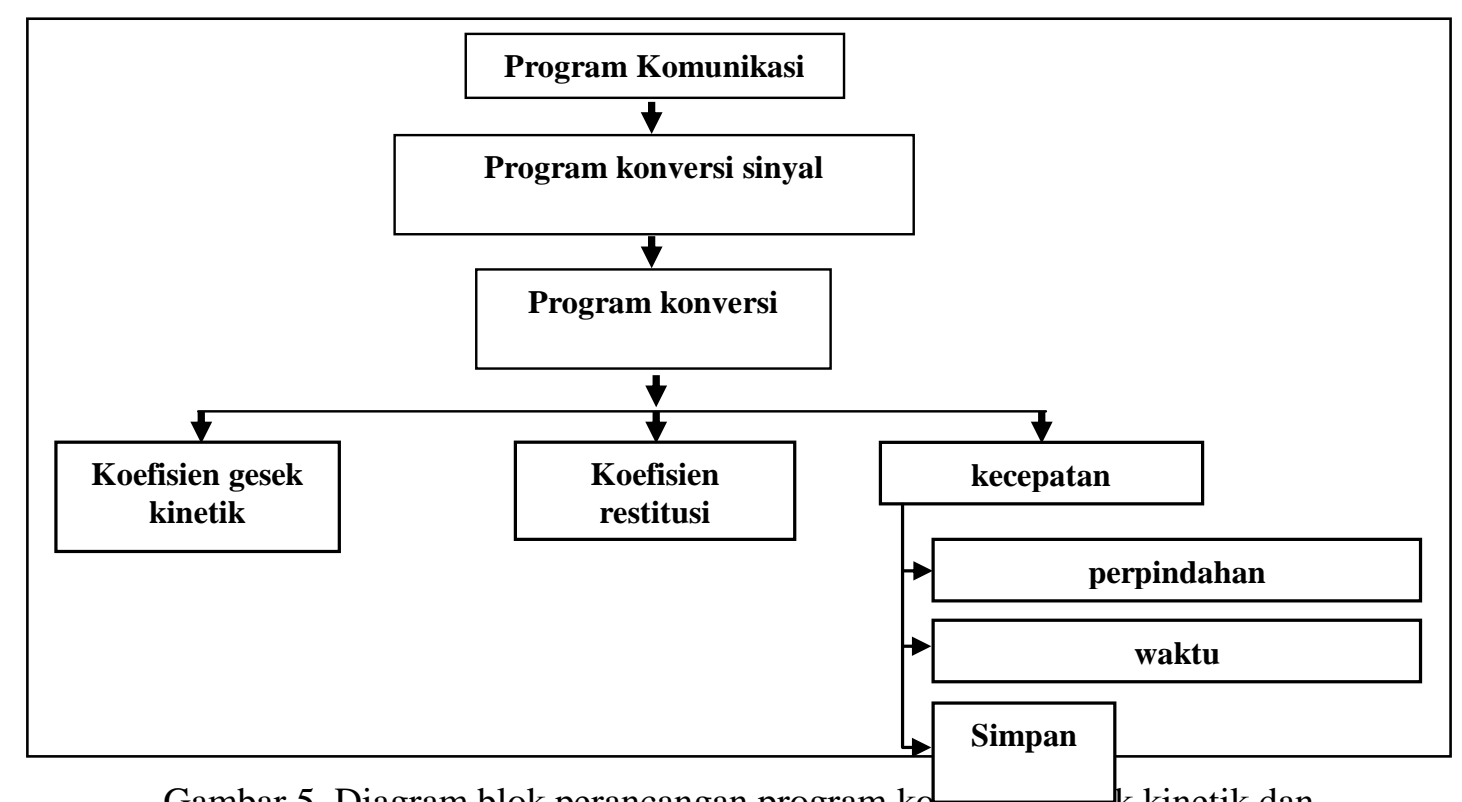

Gambar 5. Diagram blok perancangan program kotrrscrা gesek kinetik dan koefisien restitusi menggunakan perangkat lunak LabVIEW

Berdasarkan Gambar 5, perancangan program LabVIEW dibagi atas beberapa bagian. Pertama, program komunikasi serial yang berfungsi untuk membuka komunikasi data dengan mikrokontroler, Kedua, program konversi ADC ke perpidahan dan waku.
Program yang terakhir adalah program penyimpanan data.

Perancangan sensor Laser Dioda dan LDR

Dalam merancang sensor Laser Dioda dan LDR diperlukan beberapa rangkaian yaitu rangkaian sensor penangkap gerakan 1 dan rangkaian sensor penangkap perpindahan 2 . 


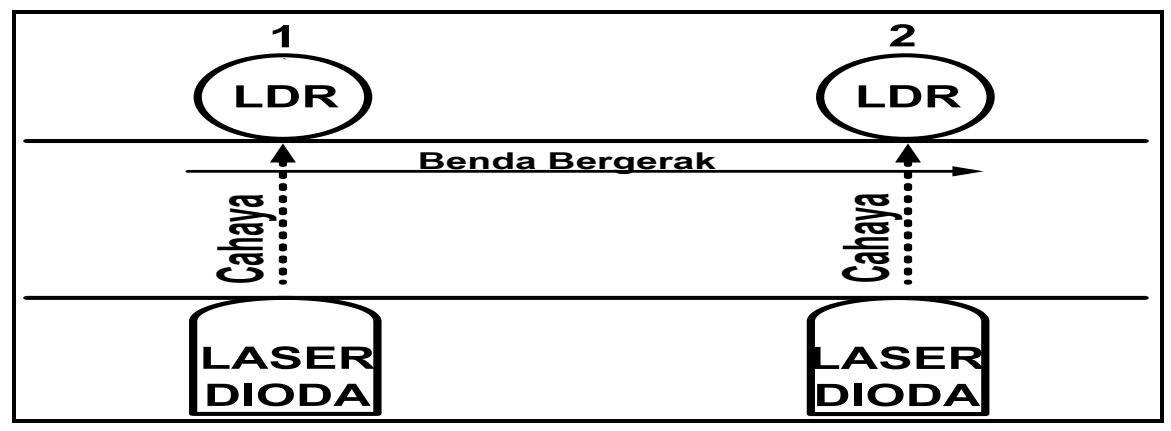

Gambar 6 Rangkaian sensor Laser Dioda dan LDR

Gambar 6 menunjukkan rangkaian sensor Laser Dioda dan LDR. Sensor Laser Dioda dan LDR berfungsi sebagai penangkap gerakan, yang mana harus berada pada posisi garis lurus agar cahaya Laser Dioda dapat ditangkap oleh
LDR. Rangkaian sensor yang satu berfungsi sebagai sensor start dan yang satunya lagi berfungsi sebagai sensor stop. Pada Gambar 7 diperlihatkan blok rangkaian sensor laser dioda dan LDR dengan arduino uno.

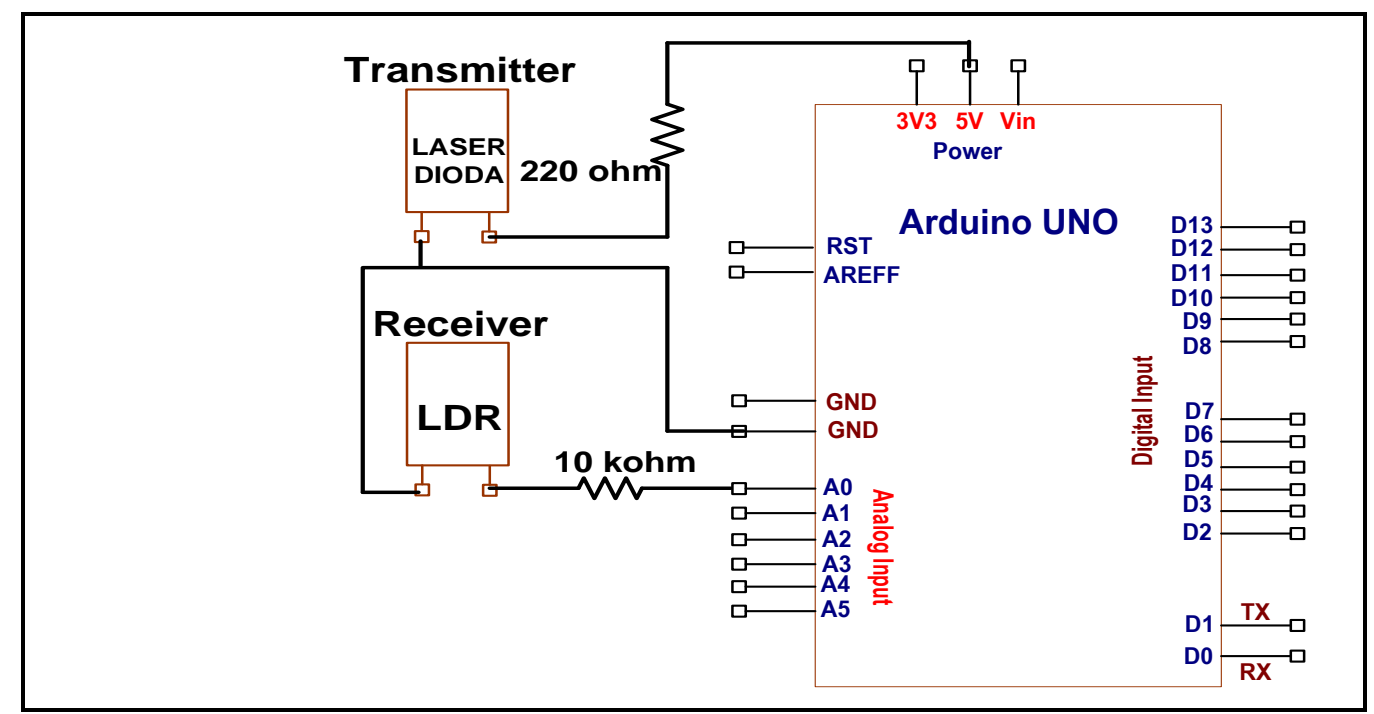

Gambar 7 Rangkaian Sensor Laser Dioda dan LDR dengan Arduino Uno

\section{Perancangan Parangkat keras Sistem}

Sistem sensor merupakan suatu sistem yang bekerja dengan mengubah stimulus menjadi energi listrik. Sistem ini terbentuk dari gabungan beberapa bagian sehingga membentuk suatu kesatuan sesuai dengan tujuan yang diinginkan. Secara umum bagian sistem sensor dibedakan atas bagian sensor sebagai pengindera, bagian pengolah sinyal keluaran sensor, bagian pemroses sinyal dan bagian penampil sinyal yang telah diproses (Fraden, 2004).

Alat ukur terdiri dari sensor Laser Dioda dan LDR dalam perancangannya menggunakan sistem instrumentasi. Stimulus dalam sistem ini yaitu waktu, sedangkan sensor sistemnya adalah Laser dioda dan LDR. Pemroses sinyal dilakukan Mikrokontroler Arduino Uno, dan 
penampil PC. Perangkat keras sistem secara keseluruhan ditunjukkan seperti Gambar 8.

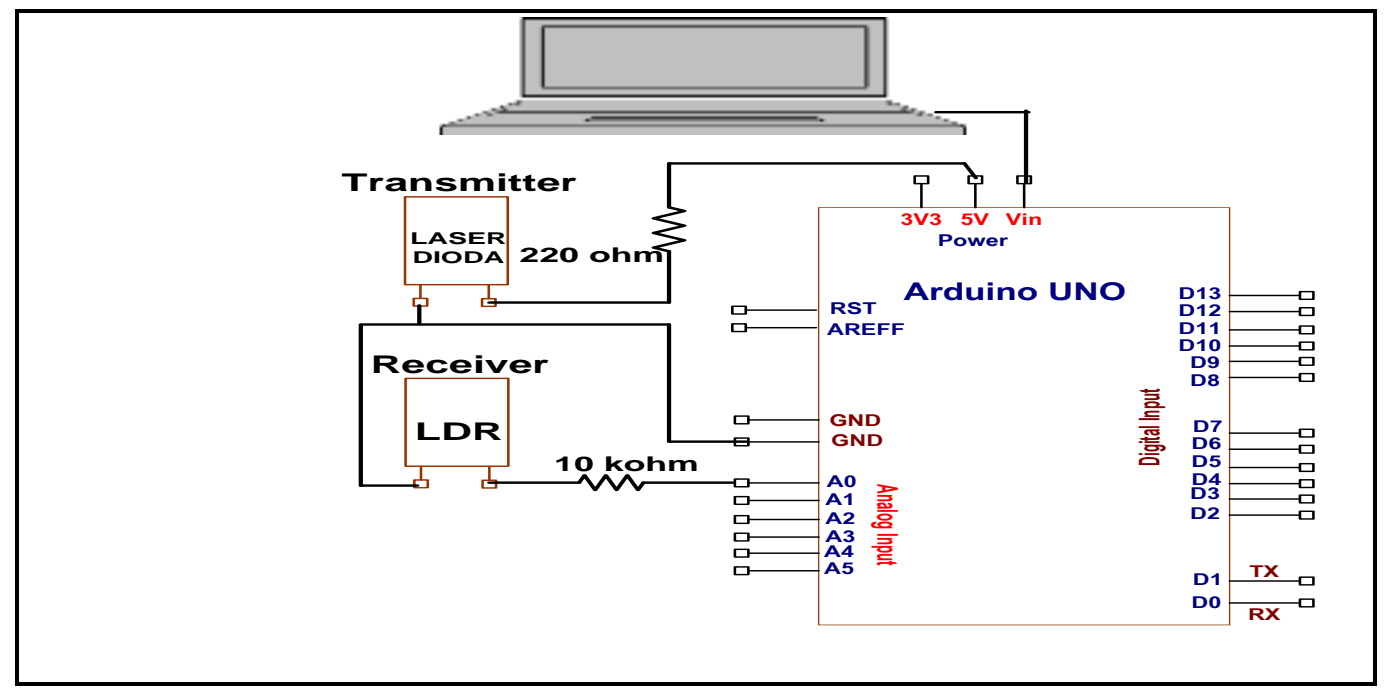

Gambar 8. Perangkat keras sistem secara keseluruhan

\section{Pengujian Alat Ukur}

Pengujian alat dilakukan dengan terlebih dahulu dengan mengkarakterisasi sistem sensor. Dengan cara menempatkan benda diantara rangkaian sistem sensor, lalu mencatat tegangan masukan yang berasal dari sensor Laser Dioda dan LDR. Hasil pembacaan alat ini kemudian dibandingkan dengan yang nilai koefisien gesek kinetik secara teori untuk mendapatkan fungsi transfer hubungan antara tegangan pada sensor dengan nilai secara teori. Prosedur yang sama dilakukan untuk beberapa perpindahan benda yang berbeda. Data tegangan sensor dan nilai secara teori kemudian diolah dengan program Excel untuk mendapatkan fungsi transfer. Fungsi transfer inilah yang kemudian dimasukkan kedalam program bahasa $\mathrm{C}$ yang digunakan sebagai kontrol penampil nilai desimal pada PC.

\section{Uji Perangkat Lunak}

Bahasa pemrograman yang telah ditulis dikompilasi dengan cara mengklik icon pada tampilan perangkat lunak IDE arduino. Selanjutnya akan ditampilkan berbagai menu dan fungsi dari masing-masing file yang akan digunakan. Data yang dihasilkan dari arduino dalam nilai digital akan ditampilkan dalam LabVIEW pada PC (personal computer).

\section{Prosedur Pengujian Alat}

Setelah alat dapat berfungsi dengan baik, maka dilakukan pengujian terhadap beberapa kondisi dan beberapa elemen yang mempengaruhi kerja sensor sebagai alat ukur koefisien gesekan kinetik dan koefisien restitusi tumbukan dua benda yaitu pengujian terhadap : 1) Karakterisasi sensor Laser Dioda dan LDR terhadap tegangan yang dihasilkan, 2) Pengujian kinerja mikrokontroler Arduino UNO terhadap sensor, 3) Pengujian kinerja hubungan PC terhadap mikrokontroler, 4) Pengujian akhir alat ukur terhadap nilai koefisien gesekan kinetik dan koefisien restitusi tumbukan dua benda

\section{Teknik Analisis Data}

Analisis data hasil pengukuran merupakan proses untuk mengetahui tingkat ketepatan dan ketelitian dari suatu sistem pengukuran. Ketepatan dari sistem pengukuran dapat ditentukan dari persentase kesalahan 
antara nilai koefisien gesek kinetik secara teori dengan nilai koefisien gesek kinetik yang diperoleh dari pengukuran menggunakan set ekseprimen yang dibuat. Persentase kesalahan dapat ditentukan dengan persamaan :

$\begin{gathered}\text { Persentase } \\ \left|\frac{\mu_{k} \text { teori- } \mu_{k^{e}} \text { eksperimen }}{\mu_{k} \text { teori }}\right| x 100 \% \text { (Djonolahan }\end{gathered} \mid=$

1984)

\section{HASIL DAN PEMBAHASAN}

\section{Pengujian Perangkat keras}

Setelah melewati beberapa tahap perancangan dan pembuatan alat, diperoleh sebuah perangkat sistem pengukuran koefisien kinetik dan koefisien restitusi tumbukan dua benda menggunakan sensor laser diodaa dan LDR berbasis Arduino UNO dengan tampilan di PC melalui pemrograman LabView seperti terlihat pada Gambar 9.

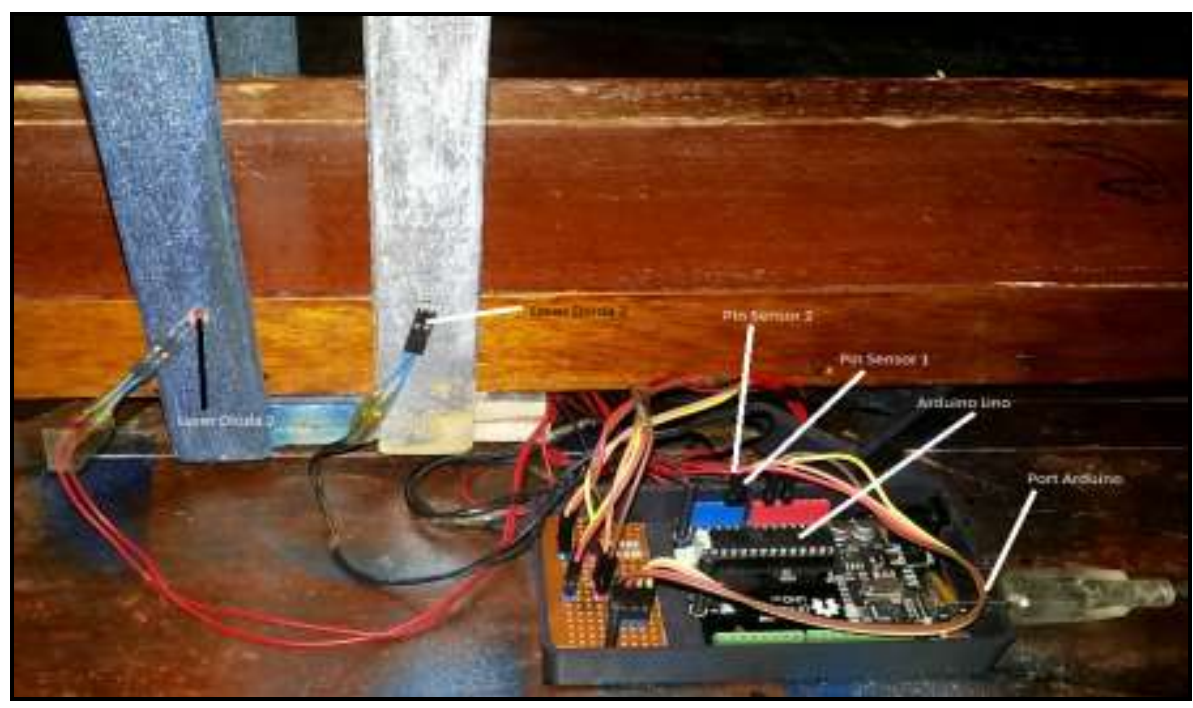

Gambar 9. Rangkaian alat ukur koefisien kinetik dan koefisien restitusi tumbukan dua benda

Untuk mengetahui apakah perangkat keras yang telah dirancang dapat bekerja atau berfungsi dengan baik sebagaimana yang diinginkan, maka dilakukan pengujian terhadap perangkat keras. Pengujian yang dilakukan terhadap perangkat keras meliputi pengujian masing-masing blok rangkaian dan pengujian terhadap gabungan dari masing-masing blok rangkaian tersebut.

\section{Karakterisasi Sensor Laser Dioda dan LDR}

Karakterisasi sensor laser diode dan LDR diperoleh dengan mengukur waktu sensor dimulai dari 1 sekon sampai 10 sekon, seperti terlihat pada Tabel 1 .
Berdasarkan hasil analisis data pada Tabel 1 dapat dijelaskan tingkat ketelitian dari pengukuran. Kesalahan relatif dari sistem pengukuran waktu berkisar antara $0 \%$ sampai 2 $\%$.

\section{Pengujian Perangkat Lunak}

Pengujian perangkat lunak dilakukan untuk melihat program yang dituliskan dalam mikrokontroler Arduino UNO bekerja sesuai dengan yang diinginkan. Program dituliskan menggunakan IDE Arduino, dengan bahasa pemrograman java dan interface menggunakan LabView dengan bahasa pemrograman grafis. Pemrograman pada Arduinno UNO hanya 
dilakukan sekali dan bisa digunakan untuk aplikasi lain jika menggunakan LabView sebagai interface. Terlebih dahulu program yang akan diisi kedalam jendela Editor Arduino ditulis secara lengkap, kemudian dikompile (verify) dan sukses (Done Compiling). Selanjutnya program ditanamkan (upload) ke dalam Arduino UNO mengunakan software IDE Arduino.

Tabel 1. Data Ketelitian Pengukuran Waktu

\begin{tabular}{cccc}
\hline No & $\mathrm{t}_{\text {ukur }}$ & $\mathrm{t}_{\text {sensor }}$ & Kesalahan Relatif (\%) \\
\hline 1 & 1 & 0.98 & $2 \%$ \\
2 & 2 & 2.03 & $1.5 \%$ \\
3 & 3 & 2.97 & $1 \%$ \\
4 & 4 & 4.02 & $0.5 \%$ \\
5 & 5 & 5.01 & $0.2 \%$ \\
6 & 6 & 5.98 & $0.33 \%$ \\
7 & 7 & 7.00 & $0 \%$ \\
8 & 8 & 7.96 & $0.5 \%$ \\
9 & 9 & 9.02 & $0.22 \%$ \\
10 & 10 & 9.98 & $0.2 \%$ \\
\hline
\end{tabular}

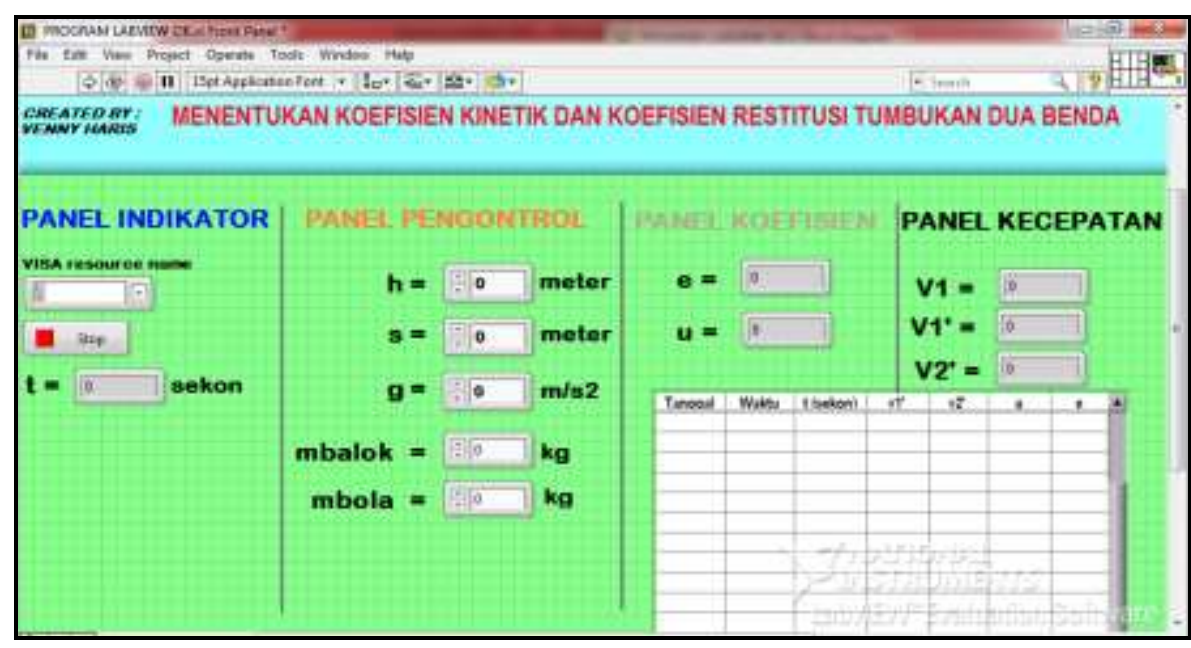

Gambar 10. Tampilan Program LabView untuk pengukuran koefisien kinetik dan koefisien restitusi tumbukan dua benda

Gambar 10 adalah tampilan program dari LabView untuk pengukuran koefisien kinetik dan koefisien restitusi tumbukan dua benda, dengan mengisikan COM yang digunakan oleh Ardino UNO sebelum menjalankan program. Selain itu, baudrate (kecepatan komunikasi) mencapai 9600 bps. Masukkan juga nilai dari tinggi, perpindahan, massa balok, massa bola dan percepatan gravitasi yang digunakan oleh Arduino UNO. Setelah itu, program siap dijalankan dengan menekan tombol run. Program akan berjalan setiap detik sesuai yang dinginkan, dan tombol stop untuk menghentikan program. Hasil dari pengukuran dapat terlihat dalam tampilan tabel. 
Hasil Pengujian Set Eksperimen Untuk Menentukan Koefisien Kinetik dan Koefisien Restitusi Tumbukan Dua Benda Secara Keseluruhan

Hasil pengujian set eksperimen untuk menentukan koefisien kinetik dan koefisien restitusi tumbukan benda secara keseluruhan dilakukan secara berulang sebanyak 5 kali dengan bidang gesekan kaca dengan kaca, baja dengan kayu dan kayu dengan kayu. Ketiga hasil tersebut ditampilak di Tabel 2, 3 dan 4. Berdasarkan data pengukuran berulang diperoleh hasil analitis statistik yang diperlihatkan pada Tabel 5.

Tabel 2. Data Hasil Eksperimen dengan Bidang Gesekan Kaca dengan Kaca

\begin{tabular}{ccccccccc}
\hline \multirow{2}{*}{$N o$} & \multirow{2}{*}{$v_{l}$} & $v_{l}{ }^{\prime}$ & $v_{2}{ }^{\prime}$ & $\boldsymbol{\mu}_{\text {Teori }}$ & $\boldsymbol{\mu}_{\text {eksp }}$ & $E$ & $\Delta \mu(\%)$ \\
\hline 1 & 0.26 & 1.183 & 0.975 & 1.038 & 0,40 & 0.399 & 0.053 & 0.25 \\
2 & 0.25 & 1.183 & 0.966 & 1.08 & 0,40 & 0.432 & 0.096 & 8.00 \\
3 & 0.26 & 1.183 & 0.975 & 1.038 & 0,40 & 0.399 & 0.053 & 0.25 \\
4 & 0.26 & 1.183 & 0.975 & 1.038 & 0,40 & 0.399 & 0.053 & 0.25 \\
5 & 0.26 & 1.183 & 0.975 & 1.038 & 0,40 & 0.399 & 0.053 & 0.25 \\
\hline
\end{tabular}

Tabel 3. Data Hasil Eksperimen dengan Bidang Gesekan Kayu dengan Kayu

\begin{tabular}{ccccccccc}
\hline No & $\mathrm{t}$ & $v_{1}$ & $v_{2}^{\prime}$ & $v_{1}^{\prime}$ & $\mu_{\text {Teori }}$ & $\mu_{\text {eksp }}$ & $\mathrm{E}$ & $\Delta \mu(\%)$ \\
\hline 1 & 0,32 & 1,41 & 0,63 & 1,32 & 0,20 & 0,20 & 0,49 & 0,00 \\
2 & 0,31 & 1,41 & 0,64 & 1,32 & 0,20 & 0,21 & 0,49 & 5,00 \\
3 & 0,32 & 1,41 & 0,63 & 1,32 & 0,20 & 0,20 & 0,49 & 0,00 \\
4 & 0,33 & 1,41 & 0,60 & 1,32 & 0,20 & 0,18 & 0,49 & 10,00 \\
5 & 0,32 & 1,41 & 0,63 & 1,32 & 0,20 & 0,20 & 0,49 & 0,00 \\
\hline
\end{tabular}

Tabel 4. Data Hasil Eksperimen dengan Bidang Gesekan Baja dengan Kayu

\begin{tabular}{ccccccccc}
\hline No & $\mathrm{t}$ & $v_{1}$ & $v_{2}^{\prime}$ & $v_{1}^{\prime}$ & $\mu_{\text {Teori }}$ & $\mu_{\text {eksp }}$ & e & $\Delta \mu(\%)$ \\
\hline 1 & 0,22 & 1,41 & 0,90 & 1,20 & 0,40 & 0,41 & 0,21 & 2,50 \\
2 & 0,23 & 1,41 & 0,87 & 1,21 & 0,40 & 0,38 & 0,24 & 5,00 \\
3 & 0,22 & 1,41 & 0,90 & 1,20 & 0,40 & 0,41 & 0,21 & 2,50 \\
4 & 0,22 & 1,41 & 0,90 & 1,20 & 0,40 & 0,41 & 0,21 & 2,50 \\
5 & 0,23 & 1,41 & 0,87 & 1,21 & 0,40 & 0,38 & 0,24 & 5,00 \\
\hline
\end{tabular}


Haris, V., \& Lizelwati, L. 2016. Pembuatan Set Eksperimen untuk Menentukan Koefisien Kinetik dan Koefisien Restitusi. Journal of Sainstek, 8(1): 38-49

Tabel 5 Koefisien Gesekan Kinetik Bahan Hasil Eksperimen

\begin{tabular}{ccccc}
\hline No & Bahan & $\mu_{\mathrm{k}}$ eksperimen & $\begin{array}{c}\mu_{\mathrm{k}} \text { teori } \\
\text { (zeamansky, 1993) }\end{array}$ & $\begin{array}{c}\text { Kesalahan } \\
\text { Relatif }(\%)\end{array}$ \\
\hline 1. & Kaca dengan kaca & 0.410 & 0.40 & 2.5 \\
2. & Kayu dengan kayu & 0.198 & 0.20 & 1.0 \\
3. & Baja dengan kayu & 0.398 & 0.40 & 0.5 \\
\hline
\end{tabular}

Berdasarkan hasil analisis data pada Tabel 5 dapat dijelaskan tingkat ketelitian dari pengukuran. Kesalahan relatif dari sistem pengukuran koefisien kinetik untuk bidang gesekan kaca dengan kaca adalah $2.5 \%$, bidang gesekan kayu dengan kayu adalah $1 \%$ dan bidang baja dengan kayu adalah $0.5 \%$. Untuk koefisien restitusi juga diperoleh nilai yang berbeda. Koefisien restitusi untuk bahan kaca dengan kaca adalah 0.062. Untuk bahan kayu dengan kayu diperoleh koefisien restitusi 0.049. Sedangkan untuk bahan baja dengan kayu diperoleh koefisien restitusinya 0.22 .

Meskipun demikian, pada sistem pengukuran menggunakan set eksperimen ini masih terdapat beberapa kelemahan dan perlu dikembangkan lebih lanjut. Pertama, sistem ini masih berupa desain. Hasil dari desain ini cukup baik, tetapi desain ini baru bisa mendeteksi waktu saja dan belum memperhitungkan faktor yang lain seperti perpindahan, sudut, dan sebagainya. Kelemahan yang kedua desain ini memiliki kelemahan dari cepatnya berubah nilai waktu yang diukur. Kelemahan ini diakibatkan ketidakstabilan tegangan keluaran sensor laser diode yang dihubungkan dengan mikrokontroler dan diperlukan rangkaian tambahan dibagian akhir untuk menjaga dari kerusakan tegangan diluar karakteristik port arduino. Kelemahan ketiga yaitu sistem ini pembandingnya masih satu alat standar, diharapkan untuk selanjutnya alat ukur ini bisa dikalibrasi dengan beberapa alat standar yang praktis. Kalibrasi menggunakan beberapa alat standar maka keakuratan alat ukur semakin baik.

\section{KESIMPULAN}

Berdasarkan data hasil dan analisis terhadap besaran yang terdapat dalam sistem pengukuran koefisien kinetik dan koefisien restitusi menggunakan sensor laser diode dan LDR dapat diambil beberapa kesimpulan sebagai berikut:

1. Desain sistem terdiri dari bagian sensor laser dioda dan LDR, serta bagian komponen elektronika. Bagian sensor laser diode dan LDR terdiri dari dua resistor. Bagian komponen elektronika terdiri dari Kit Arduino UNO. Koefisien kinetis dan koefisien restitusi dideteksi oleh sensor Laser diode dan LDR, dan datanya diolah oleh mikrokontroller Arduino UNO dan kemudian hasilnya ditampilkan melalui PC

2. Ketepatan dari sistem cukup tinggi. Sehingga kesalahan relatif yang diperoleh untuk pengukuran nilai koefisien gesek kinetik benda cukup kecil. Koefisien gesek kinetik hasil eksperimen yang diperoleh untuk bahan kaca dengan kaca adalah 0.410 , dengan kesalahan relatif $2.5 \%$. Untuk bahan kayu dengan kayu diperoleh koefisien gesek kinetik 0.198 dengan kesalahan relatif $1 \%$. Sedangkan untuk bahan baja dengan kayu diperoleh nilai koefisien gesek kinetik 0.398 dengan kesalahan relatif $0.5 \%$.

3. Koefisien restitusi yang diperoleh untuk bahan kaca dengan kaca adalah 0.062, bahan kayu dengan kayu 0.49 dan koefisien restitusi untuk bahan baja dengan kayu diperoleh 0.22 .

\section{UCAPAN TERIMA KASIH}

Penelitian ini dibiayai dari dana penelitian kompetitif dosen tingkat Madya, DIPA STAIN Batusangkar, dengan no kontrak Sti.02/IX/TL.00/2500.a/2015. 


\section{DAFTAR KEPUSTAKAAN}

Djonoputro D. 1984. Teori Ketidakpastian Menggunakan Sistem SI. Bandung: ITB.

Fraden J. 2004. The hand Book of Modern Sensor. Thermoscan. Inc, California.

Kadir A. 2013. Panduan Praktis Mempelajari Aplikasi Mikrokontroler dan Pemograman Menggunakan Arduino. Yogyakarta: Andi Yogyakarta.

Novia L. 2010. Desain alat ekperimen untuk menentukan koefisien gesekan dan koefisien restitusi tumbukan dua benda. Tesis Mahasiswa Jurusan Fisika ITB.
Putri IP, Yulkifli, Kamus P. 2015. Pembuatan Set Eksperimen Pesawat Atwood Digital Menggunakan Sensor Phototransitor Berbasis Arduino untuk Mengukur Parameter Gerak, Prosiding Seminar Nasional Pembelajaran Fisika II, Program Studi Magister Pendidikan Fisika FMIPA UNP.

Sears dan Zeamansky. 2002. Fisika Universitas (terjemahan) Edisi Kesepuluh Jilid 1.

Yohandri FM, Yohanna, Dasriyani. 2014. Pengembangan Set Eksperimen Fisika Berbasis Mikrokontroler dan Antar Muka Personal Komputer. 